\section{Igor Grbić}

\section{Genetska zabluda: književnikovi poslovi i dani, umjesto književnosti}

Izvorni znantveni rad

Original scientific paper

UDK 929:82-051>:82

82.09-021.11:808.1

\section{Nacrtak}

Članak donosi obuhvatnu analizu jedne od književnokritičkih zabluda, one genetske. Ova se očituje kad god se autorov život i okolnosti nastanka djela uzimaju u obzir kao relevantni čimbenici u kritičkoj interpretaciji i vrednovanju samog djela. Radi što jasnije kristalizacije njihova zajedničkog nazivnika, prvi je cilj članka objediniti pod genetskom zabludom razne i međusobno nedovoljno povezane oblike dosad primijećene kritičke zloporabe (biografizam, psihologizam itd.). Budući da su književnost i književna teorija i kritika svjetski fenomen, drugi je cilj sagledati problem na globalnoj razini. Pokazuje se da nijedna tradicionalna kultura nije upala u klopku poistovjećivanja pisca i njegova svijeta s književnim djelom i svijetom što ga ono stvara. Analiza zapadne situacije usredotočuje se na devetnaestostoljetni pozitivizam i njegove moderne izdanke, ali i na usporedna nastojanja oko lučenja pisca od djela. Pozornost se itekako pridaje i stajalištima samih autora. Sama autorska instanca prokazuje se u konačnici kao vrlo sporna, što samo dodatno ohrabruje fokusiranje na književnost kao takvu.

Ključne riječi: zabluda, genetska zabluda, autor, biografija, literarno djelo

U književnoj kritici zabluda (engl. fallacy) tehnički je termin za bilo koju od metodoloških pogrešaka što ih pri interpretaciji književnog djela može počiniti kritičar (ili, daleko manje tipično, sam pisac). ${ }^{1}$ Upozoravam pritom da, načelno, kritičara nikad ne treba postulirati kao zasebnu postaju na putu djela od njegova ishodišta do odredišta: kritičar je tek idealni čitatelj. Od čitatelja se on razlikuje samo u praktičnom smislu, utoliko što velika većina čitalaca nisu kritičari (iako nema čitatelja koji bi se od ikakve kritike mogao i suzdržati). Načelno, međutim, kritičar se od čitalaca ne razlikuje, nego se među njima ističe, kao čitatelj s najviše dara, obrazovanja, iskustva (prvenstveno, ali ne i isključivo čitateljskog) i discipline. On je tek najzaokruženiji, pa otud i najodgovorniji,

${ }^{1}$ Priklanjam se manjini književnih teoretičara (Northropu Fryeu i drugima) pa ni u ovom tekstu ne prihvaćam bitno podvajanje kritike i interpretacije. Valjana kritika djela ponajprije je njegova valjana interpretacija. najmjerodavniji čitatelj (očito je da i samog kritičara ovdje razmatram kao platonsku instancu, to jest kao idealnog kritičara). Sve to još i kako vrijedi kad je riječ o kritičkim zabludama. Njih laički čitatelj počinja spontano i redovito, dok čitatelj kao kritičar možda i prvenstveno odskače svojom sposobnošću da prepozna, osvijesti situacije koje zablude mogu proizvesti pa tako i osujeti njihov nastup. S obzirom na njihovu nemalobrojnost te činjenicu da im je puno lakše podleći nego odoljeti - dijelom zbog neizmjerne zavodljivosti, dijelom jer ih najprije treba uopće osvijestiti - pozornost koju su u znanosti o književnosti privukle sve je samo ne zadovoljavajuća. Očekivano, u usporedbi s artikuliranijim književnokritičkim sredinama, situacija je u nas još gora pa kritički napisi pogotovo dnevno-novinski, u obliku i mjeri u kojoj uopće i dalje postoje - vrve kritičkim zabludama svakojake vrste, a kao zasebne natuknice ne spominje ih ni Bitijev Pojmovnik suvremene književne teorije, ni Solarov Rječnik književnoga nazivlja, ni Taritašev Rječnik književne interpretacije. ${ }^{2}$ Cilj je ovog teksta raščlaniti jednu od temeljnih među tim zabludama, onu genetsku, prikazati i prokazati je kao u osnovi jedinstvenu zabludu koja se nepotrebno i štetno znade cjepkati na tobože sasvim različite zablude, te sagledati problem ne samo iz i opet fragmentarne zapadne perspektive, već - u okvirima što ih dopušta opseg jednog ovakvog teksta - na razini književnih i književnokritičkih tradicija cijelog svijeta, jedinoj razini koja doista pruža uvid u bar povijesno iskustvo književnosti kao takve, čovjeka kao takvog. ${ }^{3}$

Kao tehnički termin, zabluda je zapravo posuđena iz logike. Mada književnokritičke zablude nisu uvijek objektivno dokazive, kad su posljedica subjektivnog diskvalificiranja tuđeg ukusa, apriornog stava ili neke druge neusuglašenosti koja prethodi kritičkom postupku, često se ipak radi o pogrešci koju je u konačnici moguće svesti na logičku (a kad i nije, situacija bar površinski podsjeća na nju). Prava kritika može biti oduševljena (pa i u doslovnom smislu riječi), iskrena i nadahnuta - štoviše, dubina njenog uvida ključno i ovisi o svemu tome - ali ona ne može time nadoknaditi misaonu slabost. To je možda i najizričitije primijetio Croce (koji je itekako naglašavao i važnost nemisaone sastavnice u kritičkom postupku) kad je ustvrdio da su istinski kritičari (njegov je primjer De Sanctis) oduvijek posjedovali i veliku logičku i filozofsku snagu (Croce 2004: 41). Genetska zabluda ${ }^{4}$ dobro je sročen izraz i, da bi doista izrazila svu mnogostranost svog sadržaja, ona mora u svoje značenje uključiti sve varijacije kojima je ona ipak zajednički nazivnik. Drugim - i najjednostavnijim - riječima, genetska zabluda mora se razumjeti kao zabluda u kojoj kritičar brka djelo s njegovom genezom. A geneza obuhvaća

2 Najsustavniji meni poznati pregled većine dosad uočenih zabluda jest Strelka 1969, pogotovo poglavlje "The Problem of the Normative Fallacy" Leonarda F. Manheima (a na tragu Mauricea Beebea).

${ }^{3}$ Ovaj će članak biti u konačnici dijelom moje knjige koja će kritički, i na svjetskoj razini, razmotriti već poznate, ali i neke dosad neformulirane književnokritičke zablude.

${ }^{4}$ Izraz se obično pripisuje M. R. Cohenu i E. Nagelu ("Logic and Scientific Method", 1934.). 
kako okolnosti nastanka djela tako i instancu koju i dalje najradije poistovjećujemo s autorom djela, a to je pisac i sav njegov život, vanjski i unutarnji. Umjesto da djelo tumačimo djelom, njime samim, onime što i kako ono izgovara, mi mu prilazimo zaobilazno, kroz poslove i dane njegova zapisivača, njegove misli i osjećaje, sredinu kojoj pripada, pitamo se gdje je i kad djelo zapisao. Kritičar se u svom radu može poslužiti sad jednom sad drugom od navedenih koordinata, ali, kad god nekoj od njih dadne neopravdanu prednost nad samim djelom, ${ }^{5}$ počinja u osnovi uvijek istu zabludu.

Kao varijacija genetske zablude na pamet ponajprije padaju razne inačice devetnaestostoljetnog, pozitivističkog biografizma, sociologizma i, šire, ekologizma, kako možemo nazvati pristupanje književnosti kao posljedici djelovanja svih okolnih momenata. Takav pristup kulminirao je zloglasnim Taineovim trojstvom naroda (race), (osobnije) sredine (milieu) i (povijesnog) trenutka (moment), kao zbrojnim ključem za razumijevanje pisaca i njihovih djela, ali spomenuti treba i u nas mnogo manje spominjanog, iako u ono doba vrlo utjecajnog, Sainte-Beuvea (s kojim se, ništa čudno, antibiografistički Proust i razračunava u nizu svojih ogleda). Treba reći da je Zapad tada već bio baštinikom cijele jedne tradicije uobličavanja povijesti umjetnosti kroz životopise umjetnika. Tako su i povijesti književnosti izlistavale pjesnika po pjesnika, poredane po godini smrti, s pripadajućim životom, ponekad raspoređene u klasifikacijske podskupine. Takav se pristup može pratiti sve od Plutarha, u likovnim umjetnostima najpoznatiji su primjer Životi slavnih slikara, kipara i arhitekata Giorgia Vasarija, i do preokreta dolazi tek s Winkelmannovom Poviješću umjetnosti staroga vijeka iz 1764., gdje se puko iznošenje vremenskog slijeda i promjena proglašava nedovoljnim, a potrebnim okretanje prema povijesti stilova, prema cjelovitom predočavanju biti umjetnosti i pojma lijepog $u$ povijesnom razvoju. Pozitivističko propuštanje književnosti kroz građansku ličnost književnika postaje tim zazornije znamo li da je neposredno uslijedilo romantičarskom shvaćanju pjesnika kao čovjeka koji postoji tek u djelu i kroz djelo. Lik pjesnika strogo se luči od njegove privatne ličnosti, a kada se i čini da, upravo suprotno, romantičarski teoretičari - koji najčešće jesu pjesnici i sami - promiču jedinstvo ličnosti, to uvijek moramo iščitavati u okviru njihove teorije genija, prema kojoj se takvo jedinstvo može očitovati samo u pravog pjesnika, koji svoje pjesničko biće izlijeva u svoj "vanjski" život, ne obratno. Eckermannovi Razgovori s Goetheom uzorno su svjedočanstvo udivljenja pred tako ucijeljenom osobom. Kad tog jedinstva nema, A. W. Schlegel progovara u ime svih kad kaže da je pjesnikova biografija bespredmetna za kritički sud o djelu jer je ono "odvojeno od ličnosti svoga tvorca kao što je voće koje jedemo odvojeno od svog stabla" (nav. prema Lešić 1988: 10). Pozitivističko stajalište čista je suprotnost tomu i nije

${ }^{5}$ Nije mi dakle namjera pledirati za angloameričku novu kritiku pa u potpunosti proskribirati korištenje izvantekstovnih informacija u interpretaciji, ali s time treba biti vrlo pažljiv i ne dvojim da u golemoj većini slučajeva koji i mogu biti prihvatljivi ono obogaćuje tek naše sekundarno, tercijarno (ili koje već), ne i primarno razumijevanje djela. dosljedan izvod iz romantičarske autorske teorije, nego njena metastaza. To ne znači i da je svaka monografija o autoru kritički promašaj. Stilistička kritika upravo je monografiju učinila svojim prepoznatljivim žanrom - čime je tek ostvarivala i opet Croceov naputak da se kritika tako najbolje ostvaruje - ali stilistički kritičari u njima se i jesu bavili rekonstruiranjem "unutarnjeg" pjesnika, književnog identiteta koji proizlazi iz samih književnih značajki djela, a ne nekim tobožnjim zrcaljenjem pridruženog mu "vanjskog", uzgrednog identiteta (Tagore je prvi zvao osobnim čovjekom, a drugi fizičkim, o čemu više u nastavku članka).

Komplementarna analogija biografizmu jesu razni oblici psihologizma, to jest razmatranja djela na osnovi piščeva duševnog života. Naravno, procvat doživljava usporedo s procvatom psihoanalize, a onda i drugih dubinskih psihologija. Djelo se sad promatra kao šifrirana dijagnoza i anamneza pisca - to jest, pacijenta (za Freuda umjetnik je tek sretnik koji zahvaljujući moći sublimacije svoj libido preobražava u stvaralački čin pa tako, u uspješnijim slučajevima, amortizira neurozu koja nam je zbog seksualnih trauma svima za vratom). Psihoterapeuta (naročito njegovog osobnog) treba onda valjda razumjeti kao piščevog najmjerodavnijeg čitatelja - i kritičara. Sve u svemu, kritičarima su se daleko plodotvornijima pokazali pristupi tekstu usredotočeni na univerzalne simbole, arhetipe i miteme, ili pak takvi koji psihološki promatraju funkcioniranje samog jezika u tekstu (kao u Jacquesa Lacana ili, na drugačiji način, Émilea Benvenistea). ${ }^{6} \mathrm{Uz}$ tipičan način klasične psihološke zloporabe književne kritike, gdje je smjer djelovanja od autora prema djelu, postoji i još nevjerojatniji, ali i rjeđi i, nadam se, sasvim zastario oblik, u kojem se na temelju djela rekonstruira psihološki profil pisca. Tako je, premda Edgara Allana Poea nije poznavala, Marie Bonaparte, ponesena Freudovim otkrićima, objavila godine 1933. Poeov psihoanalitički životopis, možda i prvi takve vrste. Pomno iščitavši sav užas kojim Poeove priče vrve, te neproblematično povezavši njihove likove $i$ pripovjedače sa samim piscem, autorica je tako došla do nedvojbenog zaključka da je Poe bio incestuozni nekrofil. Sam Freud nikad, doduše, nije u svom teorijskom bavljenju umjetnošću otišao tako daleko, ali dotičnoj knjizi ipak jest napisao predgovor. Knjige takve ili slične vulgarne korespondencije bile bi samo beskorisne, kad dio kritike ne bi sirenski zavodile od stvarne književnosti pred očima, a prema nekom nestvarnom književniku iz njegovih dnevnika ili čak vlastitih maštarija.

Genetska zabluda vrlo je bliska nekim drugim zabludama, s nekima se djelomice i preklapa pa u nju valja uvrstiti i takve presjeke. Osobito vrijedi istaknuti tri, koje također zasebno obrađujem na drugom mjestu, a ovdje ih samo naznačujem. Prva je svakako zabluda namjere, jedna od najznačajnijih novokritičkih tekovina, koju kritičar počinja prvenstveno kad autorovim riječima o namjeri što ju je svojim tekstom htio ostvariti daje prednost nad onim što govori sam tekst, koji tu namjeru može ispoštovati, ali se o nju

${ }^{6}$ Više o odnosu između psihologije, naročito analitičke, i književne kritike u Grbić 2010. 
može i oglušiti. Druga je manje poznata, ali nipošto zato i rjeđa, zabluda sporenja (argumentative fallacy), gdje kritičar, umjesto da čita tekst, raspravlja s nazorima autora (kojima, da stvar bude gora, u danom tekstu možda nema ni traga). Tu se možda i najjasnije očituje zaduženost književne kritike logici jer je zabluda sporenja izravan izdanak zablude što je logičari poznaju kao argumentum ad hominem, a kod koje se zaobilazi argumentacija (su)govornika, već se kritiziraju osobine njega samog. Logički lijek u takvim slučajevima trebao bi uvijek biti pred očima i književnom kritičaru: non quis, sed quid, ne tko (je nešto rekao), nego što (je rekao). ${ }^{7}$ Treba ovdje, naravno, računati i sa suprotnom kušnjom. Primijenjeno na književnu kritiku, ako tekst ne može biti loš zato što ga je napisala osoba koju smatramo lošom, ne može biti ni dobar zato što ga je napisala osoba koju smatramo dobrom. Konačno, izdvajam zabludu koju sam nazvao metaleptičkom. Označava pogrešno preklapanje različitih stvarnosnih režima ili okvira (najčešće stvarnosti djela i vanjske stvarnosti), zbog čega više kritičkih zabluda možemo smatrati tek njenim podvrstama. ${ }^{8} \mathrm{U}$ najširem smislu, kad god čitanje samog teksta pobrkamo s čitanjem njegova pisca kao znanca, neznanca, oca, sina, supruga, političara (lijevog ili desnog), filozofa (materijalista ili idealista), vjernika ili nevjernika, simpatičnog ili antipatičnog, lijepog ili ružnog, domaćeg ili stranog, kralja ili roba, vegetarijanca, novinara, domoljuba, izdajice, entuzijastičnog ili depresivnog, ili pak s iščitavanjem okolnosti nastanka i recepcije djela - načelno počinjamo metaleptičku zabludu. Razinu na kojoj postoji djelo poistovjetili smo s razinom/razinama s kojom/kojima djelo jest spojeno očitim površinskim poveznicama, ali koje možda uopće ne odjelotvoruju istinske dubinske srodnosti i autentični identitet djela. Šlegelovski rečeno, jedemo stablo jabuke, a ne njen plod. Na tom tragu, greške što ih može počiniti u poststrukturalizmu toliko napadana intrinzična kritika (ona koja se usredotočuje na samo djelo, "autistički" ga izolirajući iz pripadajućih mu konteksta) zanemarive su u usporedbi s množinom i težinom grešaka koje stoje na raspolaganju raznim ekstrinzičnim kritikama, koje sam tekst i njegovo čitanje podređuju ili čak sasvim žrtvuju iščitavanju njegovih pretpostavljenih vanjskih odrednica, bile one društvene, povijesne, psihološke, političke, filozofske, kulturološke ili kakve već.

${ }^{7}$ Na drugom kraju povijesti čujemo jeku te krilatice u razdraženom Beckettovom prosvjedu: "Što je važno tko govori, netko je rekao, što je važno tko govori" (v. Foucault 2004: 3).

${ }^{8}$ Mada je metalepsa pojam toliko ključan da cijelu književnost (a onda, mutatis mutandis, i svu umjetnost) možemo promatrati kao veleban metaleptički fenomen (čak se i toliko problematizirana mimeza nadaje $u$ konačnici kao tek jedna od njenih inačica), ona ostaje slabo zamijećenom jedva proučenom. Metaleptička zabluda nije pak uopće formulirana i obrazložit ću je na drugom mjestu. O samoj metalepsi vidi kod nas jedino Genette 2006, a za primijenjenu metaleptičku analizu Grbić 2012.
Konačno, najvulgarniji oblik pretpostavljanja pisca djelu predstavljaju slučajevi u kojima se trenutnom zvučnošću imena prvog automatski zamjenjuje postupno čitanje drugog. Na to nailazimo neprestano. Kad neko djelo proslavi svoga pisca, sva je prilika da se, neko vrijeme ili čak doživotno, ovaj neće morati brinuti hoće li mu iduća djela biti objavljena ili ne: odsad izdaju njega, ne njegova djela. Ime na koricama zatire sve što je između njih. To, nažalost, vrijedi i za klasike, čija je svaka daljnja prosudba otežana, a katkad i onemogućena, samim procesom njihove kanonizacije i održavanja klasičnima. Može li si profesionalni istraživač književnosti dopustiti da mu se ne sviđa Shakespeare? Može li Shakespearea više ma i pročitati i sagledati mimo tradicije koja ga je pretvorila u neupitnu vrijednost, nedodirljivu svetinju, pa da sebe uopće dovede u situaciju u kojoj bi mogao primijetiti da Shakespearea on osobno baš i ne doživljava tako velikim? Koliko su službena, proklamirana stajališta takvih profesionalaca sumnjive vjerodostojnosti najbolje se vidi kad im se izbije upravo potporanj imena. Stanje se onda izokreće. Svojedobno su jedne hamburške studentske novine poslale izdavaču poglavlje rukopisnog romana nekog skroz nepoznatog pisca. Cilj je, naravno, bio objaviti roman. Izdavač je odbio rukopis. Radilo se zapravo o dijelu Musilovog Čovjeka bez svojstava (gdje se, sasvim umjesno, ironično dotiču upravo problemi književnog vrednovanja), u kojem su izmijenjena bila samo - imena. Izdavač - književni profesionalac - odbacio je dakle jedno od ključnih djela ne samo njemačkog, nego i modernizma uopće. Da se ne bi pomislilo kako je riječ o osamljenom, ekscesnom primjeru koji nikako ne može predstavljati reprezentativan uzorak, u eksperiment je uključeno ukupno desetak izdavačkih kuća. Rukopis je prihvatila samo jedna, dok su ostale redom proglasile djelo skroz beskorisnim, a samog autora nenadarenim (Strelka 1969a: vii). Umjesto otkrivanja stvari, dakle, automatizam imena. Ako pak potonje izostane, stvar ostaje sasvim neprepoznatljiva. Bez imena, bez blagoslova i, štoviše, imperativa općeg konsenzusa koji književnom profesionalcu namire popis pisaca i djela što ih mora prihvatiti, klasik se ne da identificirati, a kamoli da bi se profesionalac za svijest o njegovoj vrijednosti mogao izboriti vlastitim čitanjem.

Slavnim povikom Bog je mrtav Friedrich Nietzsche zapečatio je kraj jednog doba i izažeo bit novog, takozvanog modernog. Da bi pokušao stati nakraj novoj, antropocentričnoj, zabludi koja je time dobila svoju priliku, ni sto godina poslije Roland Barthes obznanjuje da je mrtav $\mathrm{i}$ autor te tako uvodi još $\mathrm{i}$ jedno novo, takozvano postmoderno doba. Autorski glas postaje naprosto dijelom teksta i ne postoji prije njega (Barthes 1987: 92). Autorstvo je, dodajem, u konačnici ionako nedokazivo. Nakon pozitivizma ta se instanca strahovito zakomplicirala i njegovo nam izjednačavanje autora s piscem danas izgleda iznimno naivno. Piscu (a to će reći njegovoj osobnoj svijesti), duhu vremena (čije se razumijevanje otad također zakompliciralo) te muzama, anđelima i demonima u međuvremenu su kao suatori pridruženi piščevo nesvjesno (prvo osobno, a onda i kolektivno), književna tradicija s već postojećim univerzumom tekstova (intertekstualnost, koju naznačuje već Bahtin, a razrađuju Kristeva i Barthes) te sam jezik 
(valjda svaki pisac poznaje situacije u kojima osjeća da inicijativu preuzima jezik na kojem piše, njegova logika i njegova "namjera") $)^{9}$. Navedenim se popisom u znatnoj mjeri opisuje i usporedno usložnjavanje instance okolnosti nastanka.

Na sreću, rasplinjavanje autora i okolnosti jezgrenog se dijela književne kritike ionako - ne tiču. Tekst kojim se kritičar bavi mora ponajprije biti anoniman. Susan Sontag - a pisci i prečesto pisanje vide puno jasnije od onih koji pisce proučavaju - svjedočila je naprosto ovako:

Moje knjige nisu ja - sav ja. A u nekim pogledima ja sam manje od njih. One bolje inteligentnije su od mene, nadarenije; u svakom slučaju, drugačije. "Ja" koje piše [Tagoreov osobni čovjek] preobrazba je - specijaliziranje i ažuriranje, ovisno već o tome čemu književno težim i čega se pridržavam - "mene" koji živi [Tagoreov fizički čovjek]. Tek u nekom trivijalnom smislu osjećam da je istinito reći kako ja stvaram svoje knjige. Ono što doista osjećam jest da ih, kroz mene, stvara književnost; a njima (književnosti) ja sam sluga. (Sontag 2002: 259)

Puno kraće, a uključivši i nekakav kolektivniji identitet pisca, sa svim pripadajućim okolnostima, izrazio se Kafka: "Što ja imam zajedničko sa Židovima? Jedva da mi je išta zajedničko sa mnom" (Kafka 1976: 252). Poistovjetiti čitanje priča i romana koje nam je Kafka ostavio s čitanjem njegovih pisama i dnevnika ili, s druge strane, s iščitavanjem njegovog židovstva, znači čitati Kafku, a ne književnost koju je ispisao. Njegovu prozu jest moguće čitati u judaističkome ključu (i neka takva čitanja pokazala su se vrlo poticajnima), ali ta se čitanja moraju temeljiti na činjenici da je za njih otvorena i da ih može podnijeti sama ta proza, ne na automatiziranom kratkom spoju koji će je preklopiti s ličnošću pisca. ${ }^{10}$ Odmaknemo li se od samog pisca prema okolnostima kao pretpostavljenom izvoru djela, ilustracija neka nam bude slučaj Buddenbrookovih. Kad se roman pojavio, mnogi su se stanovnici Lübecka, gdje se odvija radnja romana, našli uvrijeđenima prepoznavši se u njegovim likovima. Njihova je reakcija bila sasvim izvanknjiževna. Na njihovu reakciju reagira sad Thomas Mann, kao pretpostavljeni autor romana. I on je uvrijeđen takvim brkanjem i pita se što Libečani imaju s likovima njegova romana. Ono na što on upućuje već je književnokritička činjenica, koju nazivam metaleptičkom zabludom (brkanje, u ovom slučaju, stvarnosti svijeta i stvarnosti djela). Same kritike, naposljetku, distancirane od izvanjskog prostorno-vremenskog okvira romana (pogotovo kad nije neposredno i njen), taj se aspekt više uopće ne tiče i paziti joj je da ne podlegne genetskoj zabludi.

9 Osluškujući upravo jezik, Heidegger to izražava možda i najljepše: "Jer zapravo govori (spricht) jezik (die Sprache). Čovjek govori tek i samo ukoliko jeziku odgovara (entspricht), odazivajući se na (die Sprache). Čovjek govori tek i samo ukoliko jezki
njegov nagovor (Zuspruch)" (Heidegger 1957: 161).

${ }^{10}$ Primjerom Kafke poslužio se u tom smislu i Milan Kundera, taj veliki opominjatelj na pogibelji genetske zablude. Onog časa, kaže Kundera, kad Kafka stane privlačiti više pozornosti od Josefa K.-a započinje proces Kafkine postumne smrti (Kundera 2002: 131).
Anonimnost - doslovna ili bar kao prigušenost piščeve ličnosti - bila je samorazumljiva u nezapadnim književnostima, ali, gdje ju je uopće bilo, i u književnoj kritici, sve do utjecaja Zapada. Naravno, književnost takozvanih primitivnih (prvobitnih) zajednica listom je anonimna, i to doslovno. Sasvim je anonimna i staroegipatska književnost, uz zanimljiv izuzetak pouka, kojima su jedino pridruženi naslov i ime autora (ali se često vjeruje da je potonje tek fiktivno, preuzeto od kakve slavne osobe, čime se želi osnažiti valjanost same pouke). U mezopotamskim književnostima Gilgameš je, izgleda, jedino djelo s naslovom (Iškar Gilgāmeš, "Niz o Gilgamešu") i spomenutim autorom (Sin-leqe-unninni, "bože, primi moju molitvu"). ${ }^{11} \mathrm{U}$ starozavjetnoj predaji mudrosna se književnost također najčešće pripisivala kraljevima, tim uzorima među ljudima. Ako je pak, kao što neki pretpostavljaju, sadržajem i ugođajno sumnjiva Pjesma nad pjesmama uspjela ući u biblijski kanon jedino jer ju je predaja zarana pripisala samom kralju Salomonu, riječ je možda o prvom povijesnom primjeru ovdje već natuknute zloporabe imena kao kritičkoga jamstva. ${ }^{12}$

U Indiji se neprestano spotičemo o autorska imena koja su očito pseudonimi, a ovi su i opet zapravo imena velikih prethodnika. Tako se Vyāsi pripisuje Mahābhārata, taj najveći spjev na svijetu (dvjestotinjak tisuća stihova), ali i purāne (bar osamnaest spjevova), Brahmasūtra (temeljni tekst filozofske škole vedānta), kao i uređivanje svih četiriju Veda (vyāsa, "raščlanitelj", znači i "redaktor"), a katkad i autorstvo Yogabhāṣye (komentara Patañjalijevih Yogasūtri). Nezamislivo je da bi itko mogao u jednom životu izvesti ma i djelić svega toga. Misliti da novi autori posežu za imenom slavnog prethodnika kako bi si time priskrbili veću slavu plod je brzoplete neupućenosti: autor si je time zajamčio jedino da nitko nikad neće čuti za njega samog, dakle upravo suprotno. Pisac se za Vyāsinim imenom zaklanja, a ne ističe. Kad imena i izgledaju stvarnima, o samim piscima obično i dalje ne znamo ništa, ili se njihov život opliće legendama koje nas i opet trebaju uvesti u njihovu unutarnju veličinu kojom su nadišli same sebe, a ne u akcidentalne vanjske koordinate njihova upojedinačenog zemaljskog života. To vrijedi i za najveće (ili bi zapravo trebalo reći pogotovo za najveće). Kālidāsu i Istok i Zapad jednodušno smatraju najznamenitijim autorom klasične Indije, ali mi ne znamo ni kad je točno živio, a pretpostavke se razilaze u rasponu od gotovo tisuću godina! To je kao kad Zapad ne bi znao kad je živio Shakespeare, s kojim Kālidāsu i izričito uspoređuju pa ga nazivaju indijskim Shakespeareom. No Zapad ne samo da pouzdano zna kad se Shakespeare rodio a kad umro, nego u golemoj knjižnici ispunjenoj samo knjigama o

${ }^{11}$ Od nama pristupačnije literature, o staroegipatskoj anonimnosti v. Petrović 1982: 23 i Višcí 1993: 11, a o mezopotamskoj Reiner 1982: 44.

12 Ta je mogućnost ovdje (i u sličnim slučajevima) osobito škakljiva budući da se radi o svetopisamskom tekstu. Ako jamstvo njegove religijske vjerodostojnosti proizlazi iz tako sumnjive pripisanosti, mnogostoljetna upinjanja egzegeta, hermeneutičara i teologa općenito da amortiziraju njegovu bjelodanu putenost i otkupe je nekakvom oduhovljenom alegorizacijom možda su onda jednostavno - uzaludna. 
njemu knjige o detaljima njegova života zauzimaju zabrinjavajuće velik broj polica. Indijska se književna kritika tradicionalno bavila Kālidāsom, ne njegovim identitetom i životom, i nezapadni se istraživači nerijetko ni dandanas ne uspijevaju dovoljno načuditi strasnom radu njihovih zapadnih kolega na odgonetanju izvanpjesmovnog identiteta Crne Gospe i Prijatelja iz Shakespeareovih soneta, ili čak gospodina W. H.-a (kojemu su soneti samo posvećeni te ni ne pripada tekstu), a onda i najveće među zagonetkama: je li uopće autor svih tih djela Shakespeare kojeg poznajemo s onih nekoliko portreta, ili je to Francis Bacon, Christopher Marlowe ili neki drugi suvremenik? Nikakav odgovor ni na koje od tih pitanja ne može nikako pridonijeti našem književnom razumijevanju i uvažavanju Shakespeareovih drama i pjesama.

Istina je da je nabožno pjesništvo takozvanog indijskog srednjeg vijeka vjerojatno i najčešće pisano u prvom licu jednine, pa i da pjesnik(inja) pri kraju pjesme rado spomene i svoje ime. Ali to ja nije neko upojedinačeno ljudsko biće s vlastitom biografijom, nego svaka ljudska duša pred licem Boga. Pjesnik pjeva tek kao glasnogovornik ljudske duše, a njegovo ime ne funkcionira kao oznaka jedne određene među njima, već kao antonomazija za ljudsku dušu kao takvu. Ne treba nasjesti ni na prividno autorovo veličanje vlastitog djela. Kad marathski pjesnik Jñāneśvara (13. st.) u zazivnom dijelu svoje Bhāvārthadīpike kaže da "se ništa drugo [na svijetu] ne može usporediti s tim djelom", treba iskoristiti priliku pa pročitati i ostatak rečenice, koji u drugim sličnim slučajevima ostaje tek neizrečen: "tim zaslužnim dostignućem čije ste stvaranje u trima svjetovima vi sveci omogućili kroz moje posredništvo" (Jñāneśvara 2009: 90). Nije dakle prividno tek autorsko samoveličanje; prividan je i autor. Barthes je morao samo obnavljati zaboravljeno znanje. Prešutna pretpostavka da djelo ne izvire iz osobe koja ga naprosto zapisuje ne izostaje ni iz poetike. Tako će još na prijelazu iz šesnaestog u sedamnaesto stoljeće hindski pjesnik Keśavadāsa zabilježiti u Rasikapriyi, namijenjenoj upravo književnim pregaocima: "Ko što ljubavniku biva šteta / Kad ostane bez svoga dragana, / Trpi, strah me, i jezika poeta / Kom Rasikapriyā nije znana." (Keśavadāsa 2009: 107) ${ }^{13}$ Tradicionalna indijska kritika nikad se ne bavi privatnim životom pisca ili rekonstruiranjem okolnosti nastanka djela. Kad se i čini da bi se moglo raditi o tome, oboje se zapravo mitologizira, kako bi se, i opet, djelo i njegov pisac (točnije, pisar) upravo istrgnuli iz sfere naše stvarnosti i upisali u zbilju koja je nadilazi. Ta kritika redovito vodi računa i o tragovima iz prošlih života piščevih (saṃskāra, vāsanā), koji ostaju nepoznati pa ih kritičar, sve i da hoće, nikako ne može uključiti u svoje ekstrinzično tumačenje. Izbjegava se bilo kakva metaleptička zabluda, među ostalim i strogim razlikovanjem bhāva, osjećajnih stanja čovjeka od krvi i mesa (pa tako i pisca),

${ }^{13}$ Naravno, treba i tu očekivati izuzetke. Kad indijski muslimanski pjesnik Amir Khusrau navodi početkom 14. stoljeća deset argumenata za prvenstvo indijske mudrosti i učenosti, a zadnji je taj "da pod suncem nema takvog čarobnjaka u pjesničkom umijeću kao što je [sam] Khusrau" (Khusrau 2009: 94), teško je pronaći kontekstualni amortizator koji bi od tih riječi učinio išta više od vježbe u najosobnijoj taštini. od rasa, naoko sličnih ugođaja što ih djelo pobuđuje u čitatelju ili gledatelju, a koji su sasvim estetska, ne psihološka kategorija. Tako najveći klasični indijski kritičar, Ānandavardhana (9. st.), može reći da je Rāmāyaṇa izdanak bola što ga je osjetio njen pisac Vālmīki u osobnom iskustvu, ali on zna da je to kritici nevažna okolnost, vjerojatno i sama mitologizirana i značajna samo utoliko što nas, još i jednom, podučava o fenomenu preobražavanja privatne bhāve u univerzalnu rasu. Abhinavagupta (10./11. st.), glavn komentator Ānandavardhanina djela, jasno ističe da pjesnik nikad ne piše o svojim jadima (bhāva), već o tuđima, koje je on, osobno neupleten, naknadno okusio (i tako omogućio nastanak rase, koja doslovce i znači okus) (v. Ānandavardhana 1990: 118, bilj. 5, ali i drugdje).

Zavirimo li u Kinu, tipična je starokineska poezija "objektivna". Izbjegavaju se lične zamjenice (pa i u novijoj poeziji), a kad se i govori o sebi, to je u trećem licu, često i imenom (takvo treće lice normalna je pojava ne samo i u indijskoj poeziji, kao što je već rečeno, nego i u perzijskoj i arapskoj). Pjesnikovo ja ostaje tako neupadljivo, a osjećaj neodređenosti stvara se i osobitostima gramatike i pjesničkog jezika (neizražene kategorije lica, broja i vremena, nepostojanje formalno razlučenih vrsta riječi, međurečeničnih veza itd.). Osim toga, do neposrednog doticaja s Europom stvaralac jedva da se ikad doživljavao kao nešto zasebno. $U$ pravilu se on promatra kao dio neke književne dijade (i najveći, Li Bai, nerazdvojiv je od Du Fua), trijade ili veće književne skupine ("Sedam mudraca iz bambusova gaja" rijetko će ustupiti mjesto pojedinačnim imenima te skupine). I dandanas kineska književna kritika može nekog pisca sagledati jedino u usporedbi s nekim drugim(a). Jedinka se prevladava, a u smjeru nekog općenitijeg moralnog načela, vrlina cijelog naroda i tako dalje. ${ }^{14} \mathrm{U}$ Kini je, doduše, postojao običaj bilježenja situacija koje su poslužile kao vanjski okidač pjesničkih zapisa ali iz čitanja bar najpoznatijeg takvog djela, a to su Izvorne okolnosti pjesama (Pen shih shih) Meng Ch'ija, iz 9. stoljeća, jasno se stječe dojam da to nisu bili faktografski prilozi (a pogotovo ne takvi koji bi trebali pomoći u kritičkom radu), već, upravo obratno, da su već i to poetizirani prolozi koji uvode u osnovni ton same pjesme. Svakog petog svibnja Kinezi se još i danas prisjećaju Qu Yuana, pjesnika koji je na taj dan, 278. pr. n. e., spektakularno okončao sebi život skočivši u rijeku Miluo. Ali Qu Yuan prvi je kineski pjesnik poznat i imenom, što olakšava da, u svojoj biografskoj konkretiziranosti, bude percipiran i kao samo ishodište cjelokupne pjesničke tradicije. ${ }^{15}$ Peti svibnja nije dakle spomendan Qu Yuana, nego kineski blagdan poezije.

${ }^{14}$ Od nama pristupačnije literature, v. Lisevič 1983, naročito 7. poglavlje.

15 Ta konkretiziranost daleko je od zapadnog ideala. Njegovi životopisi također vrve kojekakvim proturječnostima i mitologizacijama (o odnosu pjesnik-djelo v. više u već klasičnom Cheng 1977). 
Okolnosti koje su pratile nastanak pjesme bilježe se i u japanskoj književnosti, a njihova esejičnost još je očitija. Riječ je o pravim umjetničkim prozama koje i tvore zaseban žanr, ka-jo. Situacija je i u japanskoj književnosti u osnovi ista. Pojedinac, sa svom svojom vlastitošću, iščezava pred djelom. Cjelokupno klasično kazalište nō možemo doživjeti kao sustavno, asketsko odustajanje glumca od sebe i prerastanje u nadjastveni lik zadan maskom (koja utoliko slučaj univerzalizira, produbljuje i potiče rađanje onoga što Indijci nazivaju rasom). Vrlo je dojmljivo izrazio taj moment Nakamura Yasuo, upozorivši da ne stavlja to glumac masku na lice, već lice ulazi u masku (v. i u Devidé 1993: 198). ${ }^{16}$ Tako je u svim tradicionalnim kazalištima. Uzmemo li drugu najpoznatiju japansku književnu vrstu, haiku, pisanje se i opet usredotočuje na objekt umjesto da izvire iz nekog subjekta. U idealnoj pjesmi pjesnikovo usijanje "urast će (naru) u stih", umjesto da pjesnik "sačinja (suru) stih". ${ }^{17} \mathrm{O}$ sabranosti na djelo, a ne na njegova pisca, japanska poetika progovara pravim pjesničkim esejima, kruna su kojih oni najvećeg japanskog poetičara, Zeamija Motokiya.

I arapsko-perzijska književnost i književna kritika variraju već poznato stajalište. Alah je istinski autor, a Kur'ān djelo što već sadrži sva djela. Čemu se baviti prividnim, ljudskim autorom i čeprkati po njegovom životu kad je moguć slučaj Tajnog ružičnjaka (Gulshan-i rāz), jednog od najvećih djela perzijske poezije? Njegov "autor", sufi Shabistarī, zapisuje da nikad nije namjeravao pisati poeziju i da se rijetko laćao pera. Pa ipak, svoje remek-djelo izveo je u samo nekoliko dana i u izravnoj nadahnutosti (ilhām) nespoznatljivoj koliko i otisci prošlih života o kojima govore indijski teoretičari - u savršeno rimovanim dvostisima i besprijekornom metru mathnawī, mada i dalje nije imao pojma o klasičnim prozodijskim kanonima. ${ }^{18}$

Anonimnost pisca i kritička irelevantnost okolnosti njegova stvaranja na Zapadu su daleko manje izražene, napose od renesanse (ili čak kasne predrenesanse), kad se on staje sve više udaljavati od tradicijskih vrijednosti. ${ }^{19}$ । dok će sredinom 19 . stoljeća

${ }^{16}$ Od nama pristupačnijih izvora, za više o japanskoj književnosti upućujem na Devidéove knjige.

17 Primijetimo da je to sačinjavanje stiha upravo etimološko značenje zapadne riječi poezija. Za navedeni ideal haikua v. i Saito 2007: 114 (knjiga pokazuje kako je to i dalje ideal ne samo i drugih japanskih umjetnosti, već i svakodnevice).

${ }^{18}$ O islamskom pristupu općenito v. Nasr 1987, gdje se navodi i Shabistarijev slučaj (93-94). Ma koliko on u nekima mogao izazivati nevjericu, inačice srećemo i u drugim tradicijama. Evo samo jednog primjera, već spomenutog Jñāneśvare, koji u onom istom tekstu piše: "Jedva da sam znao izdjeljati riječ kako najviše priliči, načeti i sustavno obraditi kakvu temu (problem) ili što su uopće govorne figure. Sve je zapravo izgovorio dobri učitelj [= Bog; moja opaska]. Od mene je načinio tek glasnogovornika, baš kao što lutka pleše ovisno već o gibanjima niti ili neke druge sprave što je pokreće" (Jñāneśvara 2009: 89).

${ }^{19}$ Zapadne analogije s ostalim tradicijama puno su izraženije u likovnim umjetnostima, koje upravo do praskozorja renesanse ostaju gotovo skroz anonimne. Anonimna su i prikazana lica. Sve do kasne gotike likovna je umjetnost dosljedno neportretna, traži nadjedinstvo u danoj mnogostrukosti te više nastoji predočiti tipični sjaj forme u predmetu. Od gotike poodmaklog 13. zapadna književna kritika doživljavati sve snažniji pozitivistički zamah, u samoj književnosti dolazi do upravo obratnog prevrata. Godine 1857. izlaze Cvjetovi zla, s kojima započinje depersonalizacija zapadne lirike. Takozvani lirski subjekt tih pjesama možda jest, a možda i nije Charles Baudelaire. Kako u svojoj zasadnoj knjizi o modernom pjesništvu primjećuje Hugo Friedrich, više nije moguće dovesti u vezu neku pjesmu iz te zbirke s nekim detaljem iz pjesnikova života, niti je ijedna od tih pjesama datirana (Friedrich 1989: 40). Ubrzo će Rimbaud stvar izvesti do krajnosti i slavno uzviknuti: Car Je est un autre (Jer ja, to je netko drugi). Iste godine kad i Baudelaireova zbirka, izlazi Flaubertova Gospođa Bovary, s čijom distanciranošću (impassibilité) pripovjedača od lika započinje depersonalizacija zapadne pripovjedne proze. "Treba se," Flaubert sad otvoreno kaže, "s naporom duha, prenositi u likove, a ne likove privlačiti sebi." (nav. prema Eco 1965: 235, bilj. 21) Još u pismu iz 1852. piše on da "[a]utor u svom poslu mora biti poput Boga u univerzumu, prisutan posvuda, a nigdje nije vidljiv" (nav. prema Wood 2008: 43). ${ }^{20}$

Jasno lučenje pisca od djela u zapadnoj će kritici započeti tek s formalizmom, dok će nova kritika uskoro tu razliku artikulirati puno izričitije, poglavito kroz zabludu namjere odnosno osjećaja. Eliotove riječi "Pjesništvo nije davanje maha emocijama, nego bijeg od emocija; ono nije izraz osobnosti, nego bijeg od osobnosti." (Eliot 1999: 15) Barthes, u kontekstu novih preokupacija kritike njegova doba, samo rekalibrira i radikalizira kad ustvrđuje razliku između djela i teksta:

Čitati neku modernu ljubavnu pjesmu kao djelo gotovo će neizbježno uključiti identificiranje autorovih ideja i osjećaja iz očitih znakova u tom djelu. Autorov ljubavni život shvatit ćemo kao označeno označiteljā iz pjesme. Čitati istu pjesmu kao tekst uključuje nas pak u golem skup kodova i konvencija, žanrova i diskursā, koji tvore moderne i tradicionalne predodžbe o ljubavi i ljubavnog pjesništva u našem društvu. Označitelji toga teksta izviru iz golemog polja kulturnih diskursa o

stoljeća viziju cjeline staje zamjenjivati vizija pojedinačnog (haecceitas), što rađa i realističkom portretistikom (v. više u Eco 2007: 107 i dalje). Pravoslavna tradicija ikona nasljeduje stariju kršćansku praksu i do lica Krista i Djevice stiže duhovnim zadubljivanjem (sozercavanjem) u njihovu kršcansku praksu i do lica Krista i Djevice stiže duhovnim zadubljivanjem (sozercavanjem) u njihovu
transcendentalnu matricu. I kad se radi o drugim portretima, ni tu se ne prikazuje vanjski, fizički čovjek, nego unutarnji (za kojeg i postoji poseban tehnički termin: ličnik). Takvo je, do modernih vremena, opće načelo i u tradicionalnim likovnim umjetnostima Azije, bar ondje gdje portretistike uopće ima. Kada, kao u Kambodži, kiparski prikazi hinduističkih bogova ili Buddhe nastaju kao portreti trenutnoga kralja, to je moguće jedino jer se u Kambodži kralj vidi kao utjelovljenje samog božanstva (v. više naročito u Zimmer 2001: 67 i drugdje). Tu je svejedno je li portret boga nastao po uzoru na lice kralja ili je portret kralja nastao po uzoru na lice božje. Njihovo je istinsko lice isto.

${ }^{20}$ Flaubert misli na biografsku nevidljivost autora. To ne treba brkati s formalističkim veličanjem Sterneovog Tristrama Shandyja upravo jer razgolićuje izvedbeni postupak: kod Sternea to zapravo čini pripovjedač, ne Sterne, i na vidjelo ne izlaze činjenice Sterneova života, nego sâmo nastajanje djela, koje tako postaje sastavnicom i djela kao konačnog ishoda. 
ljubavi, na nj i usmjeravaju našu pozornost, a to baš i nije nešto što može funkcionirati kao označeno. (Barthes 1986: 54)

Na način opet svoj i svoga doba, rekao je to i Abhinavagupta, tisuću godina prije obojice! U već spomenutom komentaru Ānandavardhane (Abhinavagupta 1990) on piše da je pjesnik koji piše o ljubavi onaj tko uživa u povodima osjećaja, njihovim učincima, kao i u prolaznim osjećajima koji se vežu uz ljubavni ugođaj (a to su sve tehnički termini same književnosti - vibhāva, anubhāva i vyabhicāribhāva - ne ljubavi), ne onaj tko je poklonik žena (640). To zna svatko tko je napisao pravu (a ne autoterapeutsku ili sličnu) ljubavnu pjesmu i kad nije bio zaljubljen u neku osobu.

Zar nas onda drugi profesori uče krivo - znaju me zapitati začuđeni studenti - kad nam govore o autorovom životu i okolnostima nastanka djela? Ne znam. Ne znam kad $i$ u kakvim prilikama to kažu. Ali za samo tumačenje - i, tko baš hoće, vrednovanje - djela ti su podaci mahom - irelevantni. To su kurioziteti, zanimljivi možda psihologiji ili sociologiji književnosti, autorovim biografima, katkad možda i tekstološki (kad se prati razvoj teksta). Uglavnom, pak, imaju upotrebnu vrijednost trača, a nerijetko se tako i koriste. Studentima uglavnom odgovoram konkretnijim primjerima, koji, onako improvizirano, mogu bolje dočarati svu zabludnost genetske zablude. Ako, o svakoj kiši, iznova pročitam meni vrlo dragu "Kišu u boriku" i tek nakon tko zna koliko vremena otkrijem da ju je napisao Gabriele D'Annunzio ("La pioggia nel pineto"), fašist, a ja sam antifašist - moj stav prema toj pjesmi mora ostati isti. I to samo iz jednog razloga: ista je ostala pjesma. Ako u njoj ima nečeg fašističkog, bilo ga je i prije moje spoznaje i moje čitanje teksta trebalo je to detektirati već tada. Ako nije, kao fašističku može je otkriti samo pažljivije čitanje nje same. Naravno, može mi na tu dimenziju pjesme ukazati i netko drugi - što i jest jedna od glavnih uloga profesora književnosti - ali mora mi na nju ukazati u samoj pjesmi. Mogući fašizam D'Annunzijeve pjesme ne smije se izvoditi (a to će, ruku na srce, značiti zapravo fabricirati) iz fašizma samog D'Annunzija. Tekst je ovakav ili onakav jer je ovakav ili onakav tekst, ne njegov pretpostavljeni autor. Navedeni primjer svjedoči i o nemogućnosti oštrog razdvajanja jedne zablude od druge, u ovom slučaju genetske od zablude sporenja. ${ }^{21}$ Isto tako, otkrije li se da neki ugledni pisac tuče svoju

${ }^{21}$ Ne mogu se složiti s uglednim istraživačem svjetske književnosti Davidom Damroschem kad (2003: 260-280) zamjera kritičarima što svoja čitanja međunarodno uspješnog Hazarskog rečnika Milorada Pavića nisu prilagodili nakon što je svojim javnim istupima njegov pisac opetovano iskazao ne samo svoje velikosrpsko opredjeljenje, nego i impliciranost te ideje u samom romanu. Slǎ̌em autorovog političkog opredjeljenja. Ali, ako ono i jest upisano u roman, presudno je što je, kad se jednom našlo u samom romanu, preobraženo u skladu sa svijetom romana. Pavićevi Hazari možda dijelom proizlaze iz stvarnih Srba, ali, kao što nisu Hazari koje poznaje povijest, tako nisu ni Srbi koje poznaje ta ista povijest. Oni su Hazari iz romana Hazarski rečnik, romana dovoljno velikog da književno amortizira, asimilira i transformira i moguću političku namjeru. Kao ikakav Srbin, Milorad Pavić kritici je jednostvno nezanimljiv. Već kao esejist koji je zapisao: "[J]a nemam biografiju. Imam samo bibliografiju." (Pavić 2005: 8) i štošta drugo nadaje se kao stalni književnokritički podsjetnik i ženu, on time prestaje biti ugledan čovjek, ali mora ostati ugledan pisac: ništa ta informacija nije promijenila u njegovim tekstovima, koje smo mi već prihvatili kao velike sa svom mogućom učitanosti obiteljskog nasilja u njih. To što je Mario Vargas Llosa opalio šaku Gabrielu Garćiiji Márquezu niti smije umanjiti moje uvažavanje Llosinih tekstova, niti, iz sućuti, uvećati moje uvažavanje Márquezovih. To može biti zanimljivo novinaru, i to žutom, ne i kritičkom čitatelju. Ako se jednom zbude da Knut Hamsun zađe kao književna veličina, to se mora zbiti jer će pasti njegova književna djela, ne jer više nećemo moći trpjeti njegov susret s Hitlerom ili činjenicu da je svoju suprugu natjerao da odustane od glumačke karijere kako bi se mogla posvetiti djeci, a on pisanju u hotelskoj sobi daleko od svih njih. Što se tiče neposrednih okolnosti geneze djela, čitao sam o skladatelju, čije sam ime u međuvremenu zaboravio, koji je rad na svojoj glazbi dopunjavao strijeljanjem uličnih mačaka iz luka. Vjerujemo li u nerazmrsivu povezanost stvaralačkog genija i čistoće duha, možemo smatrati da bi skladateljeva djela bila još bolja da nije bio okaljan takvom moralnom mrljom. Ono što ne smijemo jest naknadno prevrednovati djelo - koje već jest kakvo jest - na osnovi neke izvanumjetničke okolnosti. U svim tim i nebrojenim drugim slučajevima vrijede jezgrovite Tagoreove riječi: "Životopis pripada velikom čovjeku; pjesništvo velikom pjesniku." A ta dvojica rijetko se poklope u istoj osobi (Tagore 2001: 200). Završit ću ove primjere onime što studentima mogu reći kad čitamo Keatsovu "Odu slavuju" (Ode to a Nightingale). Svakako, ima izvantekstovnih činjenica poznavanje je kojih čitatelju poželjno, kad nije i neizostavno (što je drijada? što je Leta? tko je Ruta i kakva je njena priča? tko je ili što Hipokrena?). Ali jedno je upoznati se $s$ tipičnim biblijskim i mitološkim koordinatama same književnosti, a nešto sasvim drugo prekapati po Keatsovom životu u potrazi za kakvom zgodom koja je mogla poslužiti kao povod odi, popisivati spomene slavuja iz njegovih pisama pa slavodobitno zamahnuti svjedočanstvom Keatsova prijatelja Charlesa Browna u kojem nas ovaj obavještava o jutru kad je pjesnik, privučen pjesmom slavuja što se ugnijezdio na Brownovoj kući, podvukao stolicu pod šljivu pa nakon dva-tri sata ušao s nekakvim papirićima u ruci. Takav idolopoklonički i ovisnički stav prema akcidentalijama književnosti poniženje je za kritičara i književnu kritiku koju bi svojim radom trebao predstavljati. Informacije takve vrste ne govore nam ama baš ništa o samom pjesničkom djelu. Ono i dalje ostaje takvo kakvo je. U konačnici, pjesnicima pjeva i slavuj kojeg izvan njihove duše nije nikad bilo.

Izdavanje pisama i dnevnika književnika, koje je nakon Drugog svjetskog rata postalo prava pošast, samim je tim književnicima rijetko pomoglo, a često je naštetilo. Za književnost i književnu kritiku oni su uglavnom relevantni samo u mjeri u kojoj su i sami književnost. $U$ tom poratnom razdoblju izmijenio se i način očitovanja uspješnog književnika. On je sad medijska zvijezda koja ne mora biti toliko dobar pisac koliko dobar zabavljač, duhovit i šarmantan, fotogeničan, s osobnim mišljenjem o svemu. Njegova je

savjest, ali i majstor pera (i već to esejističko prvo lice jednine možda jest, a možda i nije Milora Pavić). Svoj pun potencijal, konačno, ostvaruje kroz svoje priče i romane. Sve su to različite ličnosti. 
književnost roba osobite (materijalne) vrijednosti, a same njegove knjige donose katkad i obilate podatke o njegovu životu (koje čitatelj i doživljava kao sastavni dio knjige pa se ljuti ako naiđe na takvo izdanje koje mu ne kaže ništa o autoru), obavezno popraćene fotoportretom (do konačne će verzije kojega biti možda odbačeno i preko stotinu prethodnih, "neuspjelih" fotografija). Takvi čitatelji i njihovi pisci teško će moći povjerovati da je bilo - i da još uvijek ima (npr. nobelovac J. M. Coetzee) - pisaca upravo suprotnog ideala. Još Flaubert - i opet - savjetuje da "[u]mjetnik mora uvjeriti svoje potomke da nije živio". Koje on veze ima s umjetninom? Maupassant se potrudio aktivno spriječiti objavljivanje njegova portreta u seriji posvećenoj slavnim piscima, a Faulkner želi "kao prvotna [= vanjska, fizička] osoba biti izbrisan i odstranjen iz povijesti, ne ostavljajući u njoj nikakva traga, ništa osim tiskanih knjiga" (ne kojekakvih nedovršenih rukopisa, pisama, dnevnika). Kundera, koji spominje ta tri primjera (Kundera 2002: 130), komentira poznatom metaforom da romanopisac ruši kuću vlastitog života ne bi li tim ciglama sagradio jednu drugu: kuću svojih romana. Biografi, dakle, zaključuje češki pisac, ruše ono što je romanopisac napravio i opet grade ono što je srušio. Kad je urednik jedne knjige skupine autora među kojima je bio i Tagore zatražio i od ovoga biografsku bilješku, pjesnik je poslao pjesmu "Pjesnikov život" (Kabicharit), u kojoj je iznio svoj "unutarnji" život. Slično tomu, kad se pojavio prvi svezak njegova dotad najcjelovitijeg životopisa (Rabindrov život (Rabindrajibani)), Tagore ga je odbacio kvalificiravši ga kao životopis unuka Dwarkanatha Tagorea (uglednog kneza i djeda pjesnikovog) (Das 2001: 385). $\mathrm{Na}$ koncu, za umjetnikovu anonimnost predano se borio i jedan od rodonačelnika postmoderne u književnosti, Italo Calvino. Biografske bilješke (koje u pravilu sastavlja sam pisac) iz njegovih knjiga vrve proturječnostima, što je međutim sasvim u skladu s onim što Germani Pescio Bottino piše u pismu od 9. lipnja 1964.:

Biografski podaci: ja sam još od onih koji, zajedno s Croceom, vjeruju da kod autora vrijede samo djela. (Kada vrijede, naravno.) Zato biografske podatke ne dajem, ili dajem pogrešne, ili ih pak uvijek nastojim izmijeniti od zgode do zgode. Slobodno me pitajte što želite znati i ja ću Vam reći. Ali nikad Vam neću reći istinu, u to možete biti sigurni. (Nav. prema Barenghi i Falcetto 1995: vii)

Calvino upisuje tu ideju u svoja djela. U njegovom metaromanesknom romanu Ako jedne zimske noći neki putnik pisac iz djela kaže: "Kako bih dobro pisao da me nema! Da se između prazne stranice i ključanja rečenica i priča, što se uobličuju i nestaju a da ih nitko ne piše, ne uvlači ta neugodna opna koju predstavlja moja osoba!" (Calvino 2004: 144-145) Na drugom mjestu - koje nas podsjeća na Rimbaudovu Krivo je reći: mislim. Moralo bi glasiti: misle me. - pisac će ovako:

Pročitao sam u jednoj knjizi da se objektivnost misli može izraziti tako da se glagol misliti upotrijebi u trećem licu, za izricanje bezličnog: reći ne "mislim", nego "misli", kao što se kaže "kiši". Ima misli u svemiru, to je konstatacija od koje uvijek moramo poći.
Hoću li ikad moći reći: "danas piše", kao što se kaže "danas kiši", "danas je vjetar"? Tek kad mi bude prirodno da glagol pisati upotrijebim u bezličnom obliku, moći ću se nadati da se kroz mene izražava nešto što je manje ograničeno od inividualnosti pojedinca. (148)

Već je rečeno: u konačnici, autorstvo je nedokazivo. Kritiku ono ni ne zanima. Ili je bar zanimati ne bi trebalo. Ne bi je trebalo zanimati ništa osim teksta, i svega što pridonosi njegovom boljem razumijevanju. A, suprotno popularnom vjerovanju, prepoznati u romanu neki detalj iz romanopiščeva života ne znači razumjeti taj roman bolje. Tko je, kad i gdje napisao neku pjesmu kritici je relevantno jedino ako su svi ti vanjski parametri postali i koordinatama samoga teksta. A s takvim izjednačavanjem treba biti krajnje oprezan, ono je moguće puno, puno rjeđe no što volimo misliti. Kao pisac i sam se iz prve ruke susrećem $\mathrm{s}$ vulgarnim poistovjećivanjem autora sa mnom, a onda još i s prvim licem mojih tekstova. Istina je, međutim, da su to sve proizvoljni automatizmi, a i kad se zasnivaju na činjenici, važnije je što je ta činjenica uzgredna. To je očita nuspojava nevidljive važnosti koja nam i dalje izmiče. Ja iz pjesme možda jest, a možda i nije pjesnik. Ja iz priče možda jest, a možda i nije pripovjedač. Čak ni esejističko $j a$ možda nije esejist sâm. Stvar je samo konvencije, zasnovane na objektivnoj učestalosti činjenice, da esejista najčešće možemo izravno prepoznati u mislima i raspoloženjima esejističkog subjekta. Ali to nipošto nije i nužno. I esej je prije svega književnost pa i u njemu moramo uvijek očekivati da njezin jezik $\mathrm{i}$ njena logika, njena zaigranost alternativna stvarnost obezvrijede ideje što ih autor možda očajnički i nastoji iznijeti kao ozbiljnu osobnu stvar. Za ozbiljnost književne kritike važno je razumjeti da mi nemamo pravo poistovjetiti pravog autora teksta $s$ imenom koje ga potpisuje, niti izvanjske okolnosti u kojima je tekst nastao s motivima i temama koji kroza nj provijavaju.

Kundera je sanjao o svijetu u kojemu bi se od pisaca i zakonom tražilo da sakriju svoj identitet te se radije uteknu pseudonimima. Od toga bi bile tri prednosti: drastično smanjivanje grafomanije, smanjenje nasrtljivosti u književnom životu i nestanak biografskog tumačenja djela (Kundera 2002: 127). Književna kritika mora preduhitriti takav zakon. Pitanje koje sam svojedobno kao student dobio na ispitu iz američke književnosti - navesti sve Hemingwayeve supruge (vremenskim slijedom, naravno) irelevantno je do skandaloznosti - i trač. To sigurno nije pitanje koje od mene trebaju očekivati moji studenti. 


\section{Popis literature}

ABHINAVAGUPTA 1990 (v. Ānandavardhana 1990)

ĀNANDAVARDHANA 1990

Ānandavardhana, Dhvanyāloka, s Abhinavaguptinim komentarom Locana, (ur. D.

H. H. Ingalls), prev. D. H. H. Ingalls, J. M. Masson i M. V. Patwardhan, Cambridge (Mass.) i London 1990.

BARENGHI I FALCETTO 1995

Mario Barenghi i Bruno Falcetto, "Cronologia", u: Italo Calvino, Perché leggere classici, Milano 1995. http://www.amazon.com/Perche-Leggere-Classici-ItaloCalvino/dp/8804401400/ref=sr_1_1?ie=UTF8\&qid=1420283729\&sr=8-1\&, kindle book (zadnja provjera 5. siječnja 2015.)

BARTHES 1986

Roland Barthes, The Rustle of Language, prev. Richard Howard, New York 1986. BARTHES 1987

Roland Barthes, Sollers Writer, prev. Philip Thody, London 1987.

CALVINO 2004

Italo Calvino, Ako jedne zimske noći neki putnik, prev. Pavao Pavličić, Zagreb 2004. CHENG 1977

François Cheng, L'écriture poétique chinoise, Pariz 1977.

CROCE 2004

Benedetto Croce, "Kritika i književna historija", u: B. Croce, Književna kritika kao filozofija, izabr. i prev. Vladan Desnica, Zagreb 2004., str. 40-43.

DAMROSCH 2003

David Damrosch, What Is World Literature?, Princeton i Oxford 2003.

DAS I CHAUDHURI 2001

Sisir Kumar Das i Sukanta Chaudhuri, "Notes", u: Rabindranath Tagore, Selected Writings on Literature and Language, (ur. i bilj. S. K. Das i S. Chaudhuri), prev. T. Bagchi i dr., New Delhi 2001., 361-413.

DEVIDÉ 1993

Vladimir Devidé, Zen: ideje, umjetnost, tekstovi, Zagreb 1993.

ECO 1965

Umberto Eco, Otvoreno djelo, prev. Nika Milićević, Sarajevo 1965

ECO 2007

Umberto Eco, Umjetnost i ljepota u srednjovjekovnoj estetici, prev. Željka Čorak, Zagreb 2007.

ELIOT 1999

Thomas Stearns Eliot, Tradicija, vrijednosti i književna kritika, prev. Slaven Jurić, Zagreb 1999.
FOUCAULT 2004

Michel Foucault, "Che cos'è un autore?", u: M Foucault, Scritti letterari, ur. i prev. Cesare Milanese, Milano 2004, 1-21.

FRIEDRICH 1989

Hugo Friedrich, Struktura moderne lirike (drugo, nadopunjeno i popravljeno izdanje), prev. Truda i Ante Stamać, Zagreb 1989.

\section{GENETTE 2006}

Gérard Genette, Metalepsa, prev. Ivana Franić, Zagreb 2006.

GRBIĆ 2010

Igor Grbić, "Jung i književnost: prilog ekstrinzičnosti u književnoj kritici", Tabula 8, Pula 2010., 84-95.

GRBIĆ 2012

Igor Grbić, "Nātyaśāstra: uvod u zbilju i njene stvarnosti", Književna smotra, 166, Zagreb 2012., 33-41.

HEIDEGGER 1957

Martin Heidegger, Der Satz vom Grund, Pfullingen 1957.

JÑ̄̄NEŚVARA 2009

Jñāneśvara, "Invocations", prev. s marathskog R. K. Bhagwat, u: Indian Literary Criticism: Theory and Interpretation, (ur. G. N. Devy), Hyderabad 2009., 74-91.

KAFKA 197

Franz Kafka, Diaries 1910-1923, Max Brod (ur.), prev. Joseph Krech, Martin Greenberg i Hannah Arendt, New York 1976

KEŚAVADĀSA 2009

Keśavadāsa, "Kinds of Poetry \& Defects of Poetry", prev. s hindskog K. P. Bahadur, u: Indian Literary Criticism: Theory and Interpretation, (ur. G. N. Devy), Hyderabad 2009., 100-107.

KHUSRAU 2009

Amir Khusrau, "Multilingual Literary Culture", prev. s hindskog R. Nath i Faiyaz "Gwaliari", u: Indian Literary Criticism: Theory and Interpretation, (ur. G. N. Devy), Hyderabad 2009., 92-95.

KUNDERA 2002

Milan Kundera, Umjetnost romana, prev. Vanda Mikšić, Zagreb 2002.

LEŠIĆ 1988

Zdenko Lešić, "Uvod: Razvoj književnokritičke svijesti od kraja XVIII do kraja XIX stoljeća", u: M. Đurčinov i dr., Moderna tumačenja književnosti, Sarajevo 1988. 5-36. 


\section{LEVY 1968}

Howard S. Levy, "The Original Incidents of the Poems", Sinologica, sv. X, br. 1, Basel 1968., 1-51.

\section{LISEVIČ 1983}

Igor Samojlovič Lisevič, Književna misao Kine. Između drevnosti i srednjeg veka, prev. Zorana Jeremić, Beograd 1983.

NASR 1987

Seyyed Hossein Nasr, Islamic Art and Spirituality, Albany 1987.

PAVIĆ 2005

Milorad Pavić, Roman kao država i drugi ogledi, Jelena Pavić (ur.), Beograd 2005.

\section{PETROVIĆ 1982}

Svetozar Petrović, "Egipatska književnost", u: Povijest svjetske književnosti, (ur. Frano Čale i dr.), sv. 1, Zagreb 1982., 9-34.

REINER 1982

Erica Reiner, "Mezopotamska književnost", Povijest svjetske književnosti, (ur. Frano Čale i dr.), sv. 1, Zagreb 1982., 35-52.

SAITO 2007

Yuriko Saito, Everyday Aesthetics, Oxford 2007.

SONTAG 2002

Susan Sontag, Where the Stress Falls, New York 2002

STRELKA 1969

Joseph Strelka (ur.), Problems of Literary Evaluation (Yearbook of Comparative Criticism, vol. II), University Park \& London 1969.

\section{STRELKA 1969a}

Joseph Strelka, "Foreword", u: Problems of Literary Evaluation (Yearbook of Comparative Criticism, vol. II), (ur. Joseph Strelka), University Park \& London 1969., i-xi.

TAGORE 2001

Rabindranath Tagore, "A Poet's Biography", prev. S. Chakravorty, u: Selected Writings on Literature and Language, (ur. S. K. Das i S. Chaudhuri), prev. T. Bagchi i dr., New Delhi 2001., 199-202.

VIŠIĆ 1993

Marko Višić, Književnost drevnog Bliskog istoka, Zagreb 1993.

WOOD 2008

James Wood, Proza na djelu, prev. Miloš Đurđević, Zagreb 2008.

ZIMMER 2001

Heinrich Zimmer, The Art of Indian Asia: Its Mythology and Transformations, (ur. Joseph Campbell), sv. 1, New Delhi 2001.

\section{Summary}

The article offers a comprehensive analysis of the genetic fallacy, one of the fallacies in literary criticism. It is manifested as considering the author's life and the circumstances in which the work was written as relevant for a critical interpretation and evaluation of the work itself. The article shows that, in order to crystallize their common denominator, the fallacy in question should be understood as embracing various kinds of critical abuse registered so far (biographism, psychologism, etc.). Since literature and literary criticism are a world-wide phenomenon, the problem is viewed in a global perspecitve, which goes to show that no traditional culture fell into the trap of identifying the writer and his world with the literary work and the world it creates. The analysis of the Western situation concentrates on the nineteenth-century positivism and its modern offshoots, but also on the parallel efforts to distinguish the writer from the work. Attention is also given to the views of authors themselves. The very authorial instance turns out to be very controversial, which should only further encourage a concentration on literature as such.

Key-words: Fallacy, genetic fallacy, author, biography, circumstances of creation, literary work. 